\title{
Constitutional Question di Mahkamah Konstitusi Sebagai Pelindung Hak Konstitusional Warga Negara Perspektif Siyasah Qadlaiyyah
}

\author{
Tarsan Umarama \\ Fakultas Syariah dan Hukum, Universitas Islam Negeri Sunan KalijagaYogyakarta \\ Email: tatarsan95@gmail.com
}

Article info

\begin{tabular}{lll}
\hline Received: Feb 13, $2021 \quad$ Revised: Feb 19, $2021 \quad$ Accepted: Apr 1, $2021 \quad$ Published: Jun 10, 2021 \\
\hline DOI: https://doi.org/10.31599/krtha.v15i1.511
\end{tabular}

Keywords : constitutional question, siyasah qadlaiyyah, human rights

Abstract : The development of state administration that have established constitutional courts, protecting the constitutional rights of citizens (buman rights). One of the protecting is the availability of judicial review access through a constitutional question. This research is descriptive exploratory. The approach in this research is a normative juridical approach with siyasah qadīīyyah theory, data sources in this research are divided into 3 (three): primary, secondary, and tertiary source. The result of this thesis research shows that the application of the constitutional question can expand constitutional protection for citizens who are involved in the litigation process in court.

Kata kunci : constitutional question, siyasah qadlaiyyah, hak asasi manusia

Abstrak : Perkembangan ketatanegaraan yang telah mendirikan mahkamah konstitusi (constitutional court), dalam perlindungan hak-hak konstitusional warga negara (hakhak asasi manusia). Salah satu di antara perlindungan itu ialah tersedianya akses judicial review melalui mekanisme constitutional question. Jenis penelitian yang digunakan dalam penyusunan tesis ini adalah penelitian pustaka (library research). Penelitian ini bersifat deskriptif eksploratif. Pendekatan dalam penelitian ini adalah pendekatan yuridis normatif dengan teori siyāsah qậäiyyah, sumber data dalam penelitian ini terbagi menjadi 3 (tiga) yaitu: sumber primer, sekunder, dan tersier. Hasil penelitian tesis ini menunjukkan penerapan constitutional question dapat memperluas perlindungan konstitusional bagi warga negara yang sedang terlibat dalam proses litigasi di pengadilan.

\section{PENDAHULUAN}

Constitutional Question adalah mekanisme review atau pengujian suatu aturan hukum yang diajukan oleh hakim yang sedang mengadili suatu perkara, dan dalam proses peradilan itu muncul pertanyaan tentang konstitusionalitas ketentuan aturan hukum yang akan 
digunakan dalam menilai dan mengambil putusan ${ }^{1}$. Mekanisme constitutional question diperlukan sebagai bagian dari upaya untuk menjamin tegaknya supremasi konstitusi dan perlindungan terhadap hak konstitusional warga negara. Dengan adanya mekanisme tersebut, (1) dapat dihindari adanya putusan hakim yang bertentangan dengan konstitusi dan melanggar hak konstitusional warga negara; (2) ruang pengujian terhadap peraturan perundang-undangan semakin luas, apalagi hakim pengadilan adalah profesi yang mempunyai kapasitas lebih untuk mengetahui adanya kemungkinan pertentangan norma; dan (3) dapat dihindari adanya pelanggaran hak konstitusional yang tidak diperlukan karena pengajuan judicial review harus menunggu adanya putusan pengadilan atau proses pengadilan dihentikan sementara.

Negara yang telah menerapkan mekanisme constitutional question, terutama negeranegara yang menganut pengujian konstitusionalitas aturan hukum melalui pengadilan (MK). Mekanisme constitutional question di beberapa negara dapat dipahami sebagai salah satu mekanisme pengujian judicial review. Constitutional Question merupakan pemberian hak kepada pengadilan untuk mengajukan pertanyaan konstitusional kepada pengadilan untuk mengajukan pertanyaan konstitusional kepada Mahkamah Konstitusi. ${ }^{2}$ Constitutional question atau pengujian norma konkret dewasa ini telah mencapai fenomena global yang telah diadopsi oleh banyak negara dengan memberikan kewenangan tersebut kepada mahkamah konstitusi. Ditinjau dari perspektif perbandingan berdasarkan pengalaman di negara-negara yang telah menerapkannya, maka negara-negara yang telah mengadopsi model pengaturan constituitional question ${ }^{3}$, siyasah qadlaiyyah hakim haruslah seorang yang berpengetahuan luas dan pandai membaca inidikasi-indikasi, petunjuk situasi dan kondisi, konflik, dan implikasi dari perkara yang diajukan kepadanya, baik yang berujud perbuatan maupun perkataan, sebagaimana kapabalitas keilmuannya mengenai hukum. Jika tidak demikian, maka dapat dipastikan keputusan hukum yang dijatuhkannya akan mengetahui kekeliruan putusan yang dijatuhkannya itu, hanya karena berpijak pada kebenaran formil semata, tanpa berusaha menggali kebenaran materliil dengan memperhatikan indikasi dan implikasi yang tampak. ${ }^{4}$

${ }^{1}$ Lihat putusan perkara 013-022/PUU-IV/2006, permohonan dikabulkan dan Pasal 134, Pasal 136, serta Pasal 137 Kuhap tentang Penghinaan terhadap Presiden atau Wakil Presiden dinyatakan bertentangan dengan UUD 1945 dan tidak memiliki kekuatan hukum mengikat.

${ }^{2}$ Moh. Mahfud MD dkk, Constitutional Question Alternatif Baru Pencarian Keadilan Konstitutional, cet. ke- 1, (Malang: Universitas Brawijaya Press, 2010), hlm. 67- 68.

${ }^{3}$ Areif Ainul Yaqin, Constitutional Question, Kewenangan yang Terlupakan dan Gagasan Untuk Melembagakannya di Mabkamah Konstitusi, cet. ke- 1, (Jakarta: Sinar Grafika, 2018), hlm. 49- 50.

${ }^{4}$ Ibnu Qayyim Al-Jauziyah, Hukum Acara Peradilan Islam, cet. ke- 2, (Yogyakarta: pustaka Pelajar, 2007), hlm. 2. 
Urgensi penerapan mekanisme constitusional question di Indonesia merupakan wujud konkret dari upaya penghormatan dan perlindungan maksimum terhadap hak-hak konstitusional warga negara. Dalam realitanya, sudah cukup banyak keluh kesah atau surat pengaduan dari warga masyarakat, baik peorangan maupun kolektif, yang masuk ke Mahkamah Konstitusi. Akan tetapi, berbagai persoalan tersebut tidak atau belum termasuk pada ranah kewenangan Mahkamah Konstitusi yang ada saat ini. Akibatnya, ruang pengujian konstitusionalitas undang-undang atau constitutional review di Indonesia masih sangat sempit, yakni hanya menjangkau pengujian norma abstrak saja dan belum mengakomodir pengujian norma konkret. Padahal, sangat mungkin persoalan konstitusionalitas dari penerapan suatu undang-undang itu muncul dari proses litigasi di pengadilan umum. Sejauh ini, hubungan antara Mahkamah Konstitusi dengan mahkamah agung dalam hal constitutional review hanya sebatas kewajiban pemberitahuan kepada mahkamah agung mengenai setiap perkara yang telah diregistrasi. Hal ini dimaksudkan agar pemeriksaan atas perkara pengujian peraturan di bawah undang-undang oleh mahkamah agung dihentikan sementara sampai adanya putusan mahkamah konstitusi atas perkara pengujian undang-undang yang menjadi sumber pengaturannya. ${ }^{5}$

Demikian juga mengenai constitutional question mengandung dua pengertian, yaitu pengertian umum dan pengertian khusus. Pengertian umum adalah istilah yang merujuk pada setiap persoalan yang berkaitan dengan konstitusi. Sedangkan dalam arti khusus, constitutional question merujuk pada suatu mekanisme pengujian konstitusionalitas undangundang, yaitu dalam hal seorang hakim yang sedang mengadili suatu perkara ragu-ragu mengenai konstitusionalitas undang-undang yang berlaku untuk perkara itu Pengertian khusus ini pada hakikatnya menggolongkan constitutional question sebagai bentuk pengujian undang-undang, sehingga termasuk sarana untuk menjamin tegaknya prinsip konstitusionalisme. Persoalannya, apakah constitutional complaint dan constitutional question dalam rangka menegakkan hak-hak konstitusional warga negara dimungkinkan menjadi kewenangan mahkamah konstitusi Indonesia. ${ }^{6}$

Pengawasan terhadap hakim tidak dapat dilepaskan dari masalah independensi hakim dan independensi kekuasaan kehakiman " Kemandirian kekuasaan kehakiman atau kebebasan hakim merupakan asas yang universal, yang terdapat di mana saja dan kapan

5 Joshua Satria Collins dan Pan Mohammad Faiz, Penambahan Kewenangan Constitutional Question di Mahkamah Konstitusi sebagai Upaya untuk Melindungi Hak-Hak Konstitusional Warga Negara, Jurnal Konstitusi, Volume 15, Nomor 4, Desember 2018, di akses pada 3 Desember 2019, hlm. 4-6.

${ }^{6}$ Hamdan Zoelfa, Constitutional Complaint dan Constitutional Question dan Perlindungan HakHak Konstitusional Warga Negara, Jurnal Media Hukum, Vol. 19 NO.1 Juni 2012, di akses pada Sabtu, tgl 20, 2021, hlm. 3 . 
saja. Asas ini berarti bahwa dalam melaksanakan peradilan, hakim itu pada dasarnya bebas, yaitu bebas dalam untuk memeriksa dan mengadili perkara dan bebas dari campur tangan atau turun tangan kekuasaan ekstra yudisial. Jadi pada dasarnya dalam untuk memeriksa dan mengadili, hakim bebas untuk menentukan sendiri cara-cara memeriksa dan mengadili. Kecuali itu, pada dasarnya tidak ada pihak-pihak, baik atasan hakim yang bersangkutan maupun pihak ekstra yudisial yang boleh mencampuri jalannya sidang pengadilan. Dari berbagai bacaan dapat diambil substansi bahwa kemerdekaan kekuasaan kehakiman merupakan syarat mutlak dan sangat fundamental bagi negara yang berlandaskan pada sistem negara hukum dan sistem negara demokrasi. Kemerdekaan kekuasaan kehakiman diartikan bebas dari pengaruh kekuasaan lainnya dalam negara dan bebas dari gangguan pihak lain dalam rangka menjalankan tugasnya. ${ }^{7}$

\section{II.METODE PENELITIAN}

Jenis penelitian ini merupakan penelitian pustaka (Library Research), yaitu penelitian yang menggunakan literatur yang sesuai dengan permasalahan yang dikaji sebagai sumber datanya, sehingga dalam menghimpun data yang dibutuhkan menggunakan sumbersumber kepustakaan yang ada kaitannya dengan masalah pokok penelitian yaitu tentang konsep dan perkembangan constitutional question yang ditinjau dari sudut pandang siyäsah qa déäiyyah. Sehingga dalam menghimpun data yang dibutuhkan menggunakan sumbersumber yang berkaitan dengan buku-buku(kepustakaan) yang ada kaitannya dengan masalah pokok penelitian yaitu tentang siyāsah qa

Penelitian ini bersifat deskriptif eksploratif, penelitian deskriptif yaitu penelitian yang bertujuan menggambarkan secara tepat sifat-sifat suatu individu, keadaan, gejala, atau kelompok tertentu atau untuk menentukan ada tidaknya hubungan antara suatu gejala dengan yang lain dalam masyarakat. ${ }^{8}$ dan bersifat eksploratif yaitu suatu metode yang berfungsi untuk memperdalam pengetahuan mengenai suatu gejala tertentu, atau mendapatkan ide-ide baru mengenai suatu gejala tertentu, penelitian eksploratif umumnya dilakukan terhadap pengetahuan yang masih baru, belum banyak informasi mengenai masalah yang diteliti, atau bahkan belum ada sama sekali.

\footnotetext{
${ }^{7}$ Imam Anshori Saleh, Konsep Pengawasan Kehakiman, cet. ke- 1, (Malang: Setara Press, 2014), hlm. 121.

${ }^{8}$ Faisan Ananda dan Watni Marpaung, Metodologi Penelitian Hukum Islam, cet. ke- 2, Jakarta: Prenada Media Group), hlm. 16.

${ }^{9}$ Ibid.
} 
KRTHA BHAYANGKARA | Volume 15 Number 1, June 2021

\section{III.PEMBAHASAN}

\section{A. Politik Peradilan Islam (Siyasah Qadlaiyyah)}

Kata qadha' menurut bahasa, memiliki beberapa arti, di antaranya: al-qadla, al-faraagh, artinya: putus, selesai. Al-qadha al-huqmu, artinya: mencegah, menghalangi-halangi, dan dari arti inilah maka qadhi-qadhi disebut sebagai hakim, karena mencegah terjadinya kejaliman orang yang mau berbuat jalim. ${ }^{10}$ Adapun definisi al-qadha dalam terminologi syariat adalah menyelesaikan persengketaan antara dua orang atau lebih berdasarkan hukum Allah swt. Dengan demikian, al-qadha (peradilan) dapat diartikan sebagai suatu kegiatan menetapkan hukum dan menyelesaikan sengketa di antara manusia serta mengembalikan hak-hak kepada pemiliknya. Al-qadha disebut juga dengan al-hukum, karena di dalam terdapat hikmah "kebijaksanaan" yang bermakna: meletakkan sesuatu pada tempatnya. Ialah yang menghentikan kezaliman seorang yang zalim dan mengembalikan hak-hak orang teraniaya dari orang yang zalim. ${ }^{11}$

Siyasah atau dapat juga dimaknai sebagai politik hukum Islam merupakan pembahasan yang mengatur urusan umum dalam pemerintahan yang berdasarkan nilainilai Islam. Pengaturan tersebut dengan menciptakan kemaslahatan dan menolak atau mencegah kemudharatan. Kemudian yang dimaknai dengan urusan umum dalam pemerintahan yang bernafaskan Islam merupakan segala sesuatu tuntutan zaman, sistem dan kehidupan sosial, baik yang berupa hukum, undang-undang, keuangan, peradilan dan lembaga eksekutif dan juga urusan undang-undang hubungan luar negeri dan dalam negeri atau maka untuk mengatur semua urusan ini, teori dan prinsip dasarnya serta membuat peraturan-peraturannya yang sesuai dengan dasar hukum adalah politik hukum Islam. ${ }^{12}$

Oleh karena manusia bersifat hilaf dan sering lupa, maka ulama Islam terdahulu mengadakan peradilan yang memelihara kesalahan dan kehilafan yang peradilan tersebut terdiri dari ulama yang terkenal luas pengetahuannya dan tajam pikirannya. Tidak boleh hakim memutuskan hukum menurut pendapatnya sendiri, kalau ada keraguan dalam suatu perkara maka hakim meminta pendapat pada alim ulama. ${ }^{13}$ Tujuan peradilan adalah menyampaikan hak kepada yang berhak dan menghentikan

${ }^{10}$ Muhammad Salam Madkur, Peradilan dalam Islam, cet. ke- 4, (Surabaya: Toko Buku Percetakan Offset, 1993), hlm. 19- 20.

${ }_{11}$ Mushthafa al-Bugha dan Mushthafa al-khan Ali al-Syurbaji, Fikih Manhaji, kitab Fikih Lengkap Imam asy-Syafi'I, (Yogyakarta: Darul Uswah, 2008),hlm. 711.

12 Cholida Hanum, Perda Syariah Perspektif Ketatanegaraan dan Siyasah Dusturiyyah, Jurnal Ilmu Syariah dan Hukum, Vol. 4, Nomor 2, 2019, di akses pada tgl 20-02-2021. Hlm. 7.

${ }^{13}$ Hasbi Ash- Shiddiqie, Sejarah Peradilan Islam, cet. ke- 3, (Jogjakarta: Bulan Bintang, 1970), hlm. 53. 
pertikaian. Menyampaikan hak adalah kemaslahatan, dan menghentikan pertikaian adalah mengangkat kerusakan, targetnya adalah meraih kemaslahatan tersebut dan melenyapkan kerusakan tersebut. Menyampaikan hak termasuk keadilan yang dengannya langit dan bumi tegak, menghentikan pertikaian termasuk menolak kezhaliman dan mudharat, dan keduanya terbagi menjadi melanggengkan yang ada dan menolak yang tidak ada, menyampaikan hak kepada yang berhak berarti menjaga yang ada dan mewujudkan maksudnya, sementara pertikaian berarti memangkas yang ada dan menolak yang tidak ada. Jika terwujud perdamaian maka hilanglah perselisihan yang merupakan salah satu dari dua tujuan. Adapun hak, bisa jadi sampai kepada pemiliknya atau pemiliknya rela meninggalkannya dan ini boleh. Jika hak terputus karena suatu keputusan dan kesaksian dan yang sepertinya, maka keputusan tersebut bisa mengakibatkan cacat pada hakim, saksi-saksi dan yang lain, ini merupakan kerusakan yang akan menimbulkan bahaya seperti saling bertikai, yang terkadang dalam keputusan itu akan timbul ketegangan di antara dua kubu yang bertikai dan yang lainnya. ${ }^{14}$

Ibnu Qayyum menguraikan bahwa tidak boleh seorang mufti maupun hakim mengeluarkan fatwa maupun putusan kecuali dengan memahami dua hal, yaitu: Pertama, memahami peristiwa dan pandangan-pandangan di dalamnya, serta menetapkan hakikat peristiwa berdasarkan qarinah, petunjuk-petunjuk, tanda-tanda, dengan mencakup sebuah ilmu. Kedua, memahami hal-hal yang wajib bagi peristiwa tersebut, yaitu memahami hukum Allah yang ditetapkannya dalam kitab-Nya atau berdasarkan firman-Nya tentang peristiwa tersebut. Setiap dua orang yang saling bertikai membawa perselisihan mereka ke pengadilan, maka hakim harus memahami apa yang dia dengar dan menyelidiki perbedaan-perbedaan antara kedua yang berselisih. Hampir tidak mungkin untuk memutuskan perselisihan tanpa memahami hal-hal yang menyebabkan perselisihan di antara pihak-pihak yang bertikai.

1. Qadhi Harus Mengetahui Perkara dengan Jelas untuk Melaksanakan Putusan

Kapanpun ada suatu perselisihan, seorang hakim harus memahami masalah dengan sebaik-baiknya, untuk kemudian memperjelas masalah-masalah antara pihak-pihak yang bertikai. Jika salah dalam memahami perselisihan, maka akan salah juga dalam membuat keputusan. Pada kenyataannya, seorang hakim membangun pemahamannya melalui saksi dan argumen-argumen dari pihak-pihak yang berselish. Untuk itu seorang hakim harus

14 Amir al- Jazzar dan Anwar al-Baz, Fatwa-Fatwa Ibnu Taimiyah, Khilafah Islamiyah, Memerangi Pemberontak, Hukum Murtad, Pengadilan Negara, Sumpah dan Nazar, Makan Halal dan Haram, cet. k- 1, Jakarta: Pustaka Sahifa, 2008), hlm. 334- 335. 
mendengarkan kedua pihak dengan baik, dan tidak memutuskan sebelum memberi kesempatan pada kedua pihak untuk memberikan pembelaan-pembelaan mereka. ${ }^{15}$

2. Unsur-Unsur Peradilan Islam

a) Hakim sebagai organ pelaksana, dalam konteks ini, hakim yang dimaksud sebagai organ pelaksana kekuasaan kehakiman adalah hakim negara yang diangkat oleh penguasa selaku waliy al-amri. Hakim itu bertugas untuk menerima, memeriksa, mengadili, dan menyelesaikan perkara, berbagai gugatan dan persengketaan.

b) Laki-laki. Menurut Maliki, Syafi'I, dan Hanbali, kelelakian itu adalah sebagai syarat mutlak untuk menjadi hakim.

c) Berakal (abliyat al-ada). Yang diartikan dengan cakap dan memiliki kemampuan untuk membedakan yang baik dan yang buruk serta dapat menempatkan sesuatu pada tempatnya, merupakan syarat utama untuk dapat menjadi hakim

d) Beragama Islam. Keislaman merupakan salah satu syarat untuk dapat menjadi hakim. Hal itu didasarkan pada pemahaman bahwa hakim memilik kesamaan dengan saksi.

e) Berlaku adil. Rumusan adil dalam pengertian ini adalah salah satu benar dalam berkata,melaksanakan tugas yang diamanatkan, menjauhi segala larangan, dan dapat mengendalikan diri dari emosi, baik pada waktu suka maupun pada saat duka.

f) Berilmu. Berilmu dalam konteks ini dapat diartikan dengan memiliki keahlian dalam bidang hukum. Ia harus mengetahii secara mendalam dasar-dasar hukum dan cabang-cabangnya, sehingga dapat membedakan antara yang hak (benar) dengan yang batil (salah).

g) Tidak cacat. Dalam hal ini, hakim harus memiliki pendengaran, penglihatan, dan pembicaraan yang sehat.

h) Penggugat (al-Muda`).Apabila hak yang dituntut itu mencakup hak manusia, maka penuntutnya adalah pemilik hak atau kuasa hukumnya. Sedangkan apabila hak yang dituntutnya itu adalah hak Allah semata-mata, termasuk di dalamnya hak publik, maka tuntutan itu dilakukan oleh penuntut umum (jaksa) sebagai wakil penguasa.

i) Tergugat (Al-Mabkum Alayh).Tergugat adalah pihak yang diadukan oleh pihak yang penggugat karena dianggap "salah" dan merugikan. Karena itu, tidak

15 Abd. Halim Talli, Asas-Asas Peradilan dalam Risalah Al-Qada, Kritik Terhadap Beberapa Asas Peradilan di Indonesia, cet. ke- 1, (Yogyakarta: UII Press Yogyakarta, 2014), hlm. 65- 66. 
selamanya seseorang tergugat itu harus menjadi pesakitan sebagai pihak yang dijatuhi vonis.

Hukuman (Vonis Hakim).Yaitu suatu putusan yang dikeluarkan majelis hakim dalam menyelesaikan suatu perkara atau persengketaan. Diktum putusan itu dapat berupa ketentuan yang harus dijalankan oleh para pihak, dapat berupa putusan untuk memiliki hak pengabulan (qadha al-ilzam), dan dapat pula berisi pembebasan dari suatu tuntutan penolakan tuntutan (qadha al-tarki). ${ }^{16}$

\section{B. Kekuasaan Penetapan Hukum (Al-sulthah Tasyriłyah)}

Dalam kajian fiqih siyāsah, legislasi atau kekuasaan legislatif disebut juga dengan al-sulthah al-tasyriyyah, yaitu kekuasaan pemerintahan Islam dalam membuat dan menetapkan hukum. Menurut Islam, tidak seorang pun berhak menetapkan suatu hukum yang akan diberlakukan bagi umat Islam. Dengan demikian, unsur-unsur legislasi dalam Islam meliputi: (a) pemerintah sebagai pemegang kekuasaan untuk menetapkan hukum yang akan diberlakukan dalam masyarakat Islam; (b) masyarakat Islam yang akan melaksanakannya; (c) isi peraturan atau hukum itu sendiri yang harus sesuai dengan nilainilai dasar syari'at Islam.

Kekuasaan legislatif adalah kekuasaan yang terpenting dalam pemerintahan Islam, karena ketentuan dan ketetapan yang dikeluarkan lembaga legislatif ini akan dilaksanakan secara efektif oleh lembaga eksekutif dan dipertahankan oleh lembaga yudikatif atau peradilan. Orang-orang yang duduk di lembaga legislatif ini terdiri dari para mujtahid dan ahli fatwa (mufti) serta para pakar dalam berbagai bidang. Di samping harus merujuk kepada nash, ijtihad anggota legislatif harus mengacu kepada prinsip jalb al-masalib dan daf al-mafasid (mengambil maslahat dan menolak kemudaratan). Ijtihad mereka juga perlu mempertimbangkan situasi dan kondisi sosial masyarakat, agar hasil peraturan yang akan diundangkan itu sesuai dengan aspirasi masyarakat dan tidak memberatkan mereka. ${ }^{17}$

\section{Sistem Syura}

Syawarahu musyawarah wa syawaraan istisyara atau meminta pendapat atau nasehat darinya". ${ }^{18}$ Yang dimaksud dengan syura, atau disebut juga masyurah adalah meminta

\footnotetext{
16 Oyo Sunaryo Mukhlas, Perkembangan Peradilan Islam dari Kabin di Jazirah Arab ke Peradilan Agama di Indonesia, cet. ke-1, (Bogor: Ghalia Indonesia, 2011), hlm. 7- 10.

${ }_{17}$ Muhammad Iqbal, Fiqih Siyasah Kontekstualisasi doktrin Politik Islam, cet. ke- 1, Jakarta: Gaya Media Pratama, 2001), hlm. 161- 163.

18 Mahmud Abd Al-Majid Al-Khaldi, Pilar-Pilar Sistem Pemerintahan Islam, cet. ke- 2, (Bogor: AlAzhar Press, 2013), hlm. 233.
} 
pendapat orang lain untuk mencapai kebenaran atau menyelesaikan masalah. Untuk mengantisipasi ketidakterbatasan kekuasaaan, maka ia tidak boleh diserah pada satu tangan/badan kekuasaan saja, artinya tidak boleh ada monopoli kekuasaan yang terpusat pada satu badan. Hal ini penting mengingat kecenderungan manusia yang diberi amanah mengendalikan kekuasaan melakukan tindakannya yang melampaui batas sewenangwenang. Dalam kontkes ini, Allah memerintahkan untuk melakukan musyawarah. ${ }^{19}$

Maka berkat rahmat Allah engkau (Muhammad) berlaku lemah lembut terbadap mereka. Sekiranya kamu bersikap keras dan berbati kasar, tentulah mereka menjaubkan diri dari sekitarmu. Karena itu maafkanlah mereka dan mohonkanlah ampun untuk mereka dalam urusan itu. Kemudian, apabila engkatu telah membulatkan tekad, maka bertawakallah kepada Allah. Sungguh, Allah mencintai orang yang bertawakal. ${ }^{20}$

Hukum-hukum yang berkaitan lansung dengan nash-nash yang jelas dan terang, baik itu yang berasal dari Al-Quran, Sunnah, ataupun ijmak. Hukum-hukum ini tidak ada urusannya dengan syura, artinya: siapa pun tidak dapat mengubah atau menukarnya, walau siapa pun orangnya dan bagaimanapun kedudukannya. Pada hukum-hukum ini, seorang pemimpian berkewajiban menyuruh umat untuk melaksanakannya walau dengan paksa. Hukum ini dapat terbagi menjadi dua bagian: (a) Hukum-hukum yang telah ditetapkan oleh Allah Swt, yang tercakup dan dapat dipahami melalui Al-Quran, Sunnah, ijmak atau qiyas, tetapi hukumnya masih samar sehingga memerlukan istinbath penemuan hukum dari dalil-dalil terebut melalui ijtihad. Artinya, hukum-hukum ini disampaikan oleh Allah Swt secara global, dan para mujtahidlah yang berkewajiban menjelaskannya kepada umat. Para mujtahid tersebut berasal dari ulama-ulama, kaum muslimin, baik dia berkedudukan sebagai pemimpin ataupun rakyat biasa. (b) Hukum-hukum yang diturunkan Allah Swt secara umum saja.

Adapun mengenai perincian dan mekanisme penerapannya diserahkan sepenuhnya berdasarkan kemaslahatan kaum muslimin, sesuai dengan situasi dan kondisi kehidupan mereka yang terus berkembang. Kelompok hukum yang kedua ini tunduk pada ketentuan syura. Artinya, seorang imam tidak begitu saja menetapkannya kecuali setelah melakukan konsultasi dan syura dengan jumlah ulama dan mujtahid yang ada. Perlu diketahui bahwa syura tidak dapat mengikat seorang pemimpin dalam membuat keputusan. Artinya, bahwa imam tersebut tidak wajib menerima pendapat yang terbanyak dalam Majelis Syura tersebut, seperti halnya dalam sistem demokrasi. Akan tetapi, seorang imam berkewajiban berkonsultasi dengan orang-orang yang berilmu dan ahli serta 
meminta pendapat mereka. Sebab, barangkali imam tersebut luput mengetahui hal-hal yang justru diketahui oleh para pakar tersebut. Dan setelah para ahli dan ulama tersebut mengemukakan pendapat dan pandangan mereka, maka imam dapat memilih pendapat mana yang dirasa lebih dekat kepada kebenara, serta hukum yang paling sesuai dengan hukum Allah swt. ${ }^{21}$

Kebebasan merupakan kehendak sadar untuk memilih antara meniadakan atau mengakui sesuatu dalam eksistensi. Sedangkan demokrasi adalah praktik kebebasan yang dilakukan sekolompok manusia sesuai dengan otoritas pengetahuan, etika, estetika, adat dan istiadat. Aturan penelitian ilmiah tidak selalu sesuai untuk menetapkan berbagai macam hukum dalam kehidupan sosial masyarakat. Sementara berbagai bentuk konflik dan interaksi timbal balik sehari-hari melahirkan problematika baru. Karenanya, adanya berbagai pendapat yang berlainan dalam masyarakat merupakan satu-satunya cara pemecahan masalah yang ilmiah dan kredibel untuk menjadi perwujudan demokrasi. Sesungguhnya perbedaan pendapat, kebebasan berekspresi dan semua perwujudannya dalam berbagai bentuk lembaga, partai politi, ataupun institusi hukum, adalah satu-satunya metode ilmiah bagi pemecahan problematika kehidupan masyarakat kontemporer. Sebagaimana diketahui, kebebasan merupakan kehendak sadar manusia untuk memilih antara menafikkan dan menetapkan sebuah eksistensi dalam kehidupan. Kebebasan manusia harus diwujudkan dan tidak bisa diganggu oleh otoritas undang-undang dasar yang disepakati. Praktik kebebasan secara utuh harus dilindungi oleh Undang-Undang Dasar sebuah negara (dustur). Undang-Undang Dasar ini memberikan kerangka rujukan untuk dua pilihan: antara penolakan dan penerimaan. Sedangkan cara penerapannya diatur oleh perundang-undangan yang disepakati (qanun).

Karena asas kehidupan Islam adalah kebebasan dan kebolehan (ibahab), maka manusia dapat mengekspresikan pendapatnya tanpa membutuhkan izin dari siapapun. Dalam Tanæil Hakim ada istilah khas demokrasi, yakni syura. Syura adalah praktik sekelompok manusia untuk terbebas dari otoritas apapun. Kita sebagai umat muslim harus melihatnya dengan kacamata kontemporer yang berpijak pada dialektika manusia, sebagaimana undang-undang yang sedang berlaku, baik kita kehendak atau tidak. Kita harus paham bahwa ketika kita mengekang kebebasan syura, kebebasan ide, kebebasan

${ }^{21}$ Mushthafa al-Bugha dan Mushthafa al-khan Ali al-Syurbaji, Fikih Manhaji, kitab Fikib Lengkap Imam asy-Syafi'I, hlm. 836- 838. 
memilih salah satu dari yang berlawanan, kebebasan bukti-bukti ilmiah dan kebebasan undang-undang definitif yang ada. ${ }^{22}$

\section{Kekuasaan al-Madzalim (Qàdha mazhalim)}

Kata wilāyah al-mazalim merupakan gabungan dua kata, yaitu wilāyah dan al-mazalim. Kata wilayah secara literal berarti kekuasaan tertinggi, aturan, dan pemerintahan. Sedangkan kata al-mazalim adalah bentuk jamak dari mä̧limah yang secara literal berarti kejahatan, kesalahan, ketidaksamaan, dan kekejaman. Sedangkan terminologi wilāyah al-maralim berarti "kekuasaan" pengadilan yang lebih tinggi dari kekuasaan hakim dan mubtasib, yang bertugas memeriksa kasus-kasus yang tidak masuk dalam wewenang hakim biasa, tetapi pada kasus-kasus yang menyangkut penganiyaan yang dilakukan oleh penguasa terhadap rakyat biasa. Wilayah al-mazalim bertugas untuk mengadili para pejabat negara, meliputi para khalifa, gubernur, dan aparat pemerintah lainnya yang berbuat zalim kepada rakyat.Wilayah al-Mazalim sudah dikenal di Arab sebelum Islam. Hal ini wujud dari komitmen orang-orang Quraisy untuk menolak segala bentuk kezaliman sekaligus memberikan pembelaan terhadap orang-orang yang dizalimi. ${ }^{23}$

\section{E. Penemuan Hukum (rechtsvinding)}

Pada dasarnya, penemuan hukum muncul sebagai akibat tidak lengkap atau tidak jelasnya peraturan perundang-undangan tertulis yang ada, sehingga untuk memutus suatu perkara maka hakim harus melakukan kreasi aktifnya guna menemukan solusi hukum. Kreasi aktif dalam bentuk melakukan penemuan hukum ini perlu dilakukan oleh hakim karena hakim bukan hanya tidak boleh menolak suatu perkara dengan alasan tidak ada atau kurang jelas dasar hukumnya, tetapi juga tidak boleh memutus suatu perkara dengan alasan yang sama. Hakim dianggap mengetahui hukumnya (ius curia novit). Artinya, melalui penemuan hukum itu hakim mengisi kekosongan hukum (rech vacum). Itulah sebabnya, maka "penegakan dan pelaksanaan hukum sering merupakan penemuan hukum dan tidak sekedar penerapan hukum. Ada tiga alasan atau dasar pemikiran mengapa hakim harus melakukan penemuan hukum, yaitu: (1) Karena peraturannya tidak ada, tetapi esensi perkara sama atau mirip dengan suatu peraturan lain yang dapat diterapkan pada kasus tersebut; (2) Peraturannya memang ada, tetapi kurang jelas sehingga hakim perlu menafsirkan peraturan tersebut untuk diterapkan pada perkara yang ditangani; (3)

22 Muhammad Syahrur, Tirani Islam Genealogi Masyarakat dan Negara, cet. ke- 1, (Yogyakarta: LkiS Yogyakarta), hlm. 147- 149.

${ }^{23}$ H. A. Basiq Djalil, Peradilan Islam, cet. ke- 1, (Jakarta: Sinar Grafika Offset, 2012), hlm. 113-114. 
Peraturannya juga ada, tetapi peraturan itu sudah tidak sesuai lagi dengan kondisi dan kebutuhan warga masyarakat, sehingga hakim wajib menyesuaikannya dengan perkara yang sedang ditangani. ${ }^{24}$

Jadi tugas penting dari hakim ialah menyesuaikan undang-undang dengan hal-hal nyata di masyarakat. Apabila undang-undang tidak dapat dijalankan menurut arti katanya, hakim harus menafsirkannya. Dengan kata lain apabila undang-undangnya tidak jelas, hakim wajib menafsirkannya sehingga ia dapat membuat suatu keputusannya yang adil dan sesuai dengan maksud hukum yaitu menacapai kepastian hukum. Atas dasar itulah, orang dapat mengatakan bahwa menafsirkan undang-undang adalah kewajiban hukum dari hakim. Hakim wajib mencari kehendak pembuat undangundang, karena ia tidak boleh membuat tafsiran yang tidak sesuai dengan kehendak itu. Setiap tafsiran adalah tafsiran yang dibatasi oleh kehendak pembuat undang-undang. ${ }^{25}$

\section{F. Tinjauan Siyasah Qadlaiyyah dalam Perlindungan Hak Konstitusional Warga Negara}

Dalam hubungannya, Siyasah Qadlaiyyah adalah “pengelolaan masalah umum bagi negara bernuansa Islam yang menjamin terealisirnya kemaslahatan dan terhindar dari kemudaratan dengan tidak melanggar ketentuan syariat dan prinsip-prinsip syariat umum meskipun tidak sesuai dengan pendapat-pendapat para imam mujtahid. Yang dimaksud dengan masalah umum (sosial) bagi negara adalah setiap urusan yang memerlukan pengaturan baik mengenai perundang-undangan negara, kebijakan dalam penetapan hukum, kekuasaan kehakiman (peradilan). Dalam pandangan Siyasah Qadlaiyyah, constitutional question mempunyai pengaruh yang kuat membuat kebijakan-kebijakan, maupun keputusan hukum dalam peradilan. Definisi-definisi tersebut menegaskan bahwa wewenang segala bentuk hukum, peraturan dan kebijaksanaan yang berkaitan dengan pengaturan kepentingan negara dan urusan umat guna mewujudkan kemaslahatan umum terletak pada pemegang kekuasaan (pemerintah, qādhi).

Karena segala bentuk itu hukum, peraturan dan kebijaksanaan siyasah yang dibuat oleh pemegang kekuasaan bersifat mengikat wajib ditaati oleh masyarakat selama produk itu secara substansial tidak bertentangan dengan jiwa syariat. Dapat disimpulkan bahwa fiqibsiyäsahqadaīah adalah ilmu yang mempelajari hal-ihwal dan seluk-beluk pengaturan

${ }^{24}$ Munafrizal Manan, Penemuan Hukum oleh Mabkamah Konstitusi, cet. ke- 1, (Bandung: Mandar Maju, 2012), hlm. 15- 16.

${ }^{25}$ Bambang sutiyoso, Metode Penemuan Hukum, Upaya Mewujudkan Hukum yang pasti dan Berkeadilan, cet. ke- 2, (Yogyakarta: UII Press Yogyakarta, 2007), hlm. 82- 83. 
urusan umat dan negara dengan segala bentuk hukum, peraturan hukum dan kebijaksanaan yahng dibuat oleh pemegang kekuasaan yang sejalan dengan dasar-dasar ajaran konstitusi (syariat) untuk mewujudkan kemaslahatan umat. Dalam konteks pengertian tersebut tugas siyäsahqa dajyah adalah mempelajari segala sebab musabab, segala masalah dan aspek yang berkaitan dengan kebijakan negara dalam masalah umum (sosial) serta peranannya dalam kehidupan umat, dan segala bentuk hukum, peraturan dan kebijaksanaan yang dibuat oleh penguasa. Dari beberap pengertian di atas dapat pula diketahui adanya hubungan antara siyāsahqadaīyahdan constituional question dalam sistem ketatanegaraan dalam Islam. Hukum-hukum yang digali dari sumber yang sama dan ditetapkan untuk mewujudkan kemaslahatan. Kemudian hubungan keduanya dipandang sebagai bagian dari ilmu fiqì siyāsah. ${ }^{26}$

\section{KESIMPULAN}

Secara konsepsional maupun yuridis konstitusional, mekanisme constitutional question dapat dilembagakan atau dikonstruksikan sebagai bagian dari kewenangan mahkamah konstitusi dalam menguji Undang-Undang terhadap Undang-Undang Dasar sebagaimana dimaksud oleh Pasal 24C ayat (1) UUD 1945, dan memperluas sarana perlindungan konstitusional bagi warga negara yang sedang terlibat dalam proses litigasi di pengadilan agar tidak dihukum berdasarkan undang-undang yang masih diragukan konstitusionalitasnya

Dalam tinjauan siyāsah qaḍäiyyah (politik peradilan), lembaga penetapan hukum (siyäsah tasyri'iyyah), dan hak asasi manusia, constitutional question tentu sangat urgen untuk diterapkan di mahkamah konstitusi, selain itu dari sisi original intent tidak ditemukan adanya larangan atau pembatasan untuk mengelaborasi kewenangan constitutional question untuk diterapakn di mahkamah konstitusi. Artinya secara konstitusional mekanisme constitutional question ini memang dapat dilembagakan atau dilekatkan sebagai bagian yang integral dari kewenangan mahkamah konstitusi sehingga terwujudnya keadilan sosial bagi seluruh masyarakat dan yang terpentingnya adalah terlindunginya masyarakat dari penerapan pasal-pasal yang pasal tersebut masih diragukan konstitusionalitasnya sehingga perlu dipertanyakan di mahkamah konstitusi, dengan begitu hak-hak konstitusional warga negara/atau hak asasi manusia dapat terlindungi dari penerapan pasal tersebut.

${ }^{26}$ J. Suyuthi Pulungan, Fiqih Siyasah, Ajaran Sejarah dan Pemikiran, cet, ke-4, (Jakarta: RajaGrafindo Persada, 1999), hlm. 23- 27. 
KRTHA BHAYANGKARA | Volume 15 Number 1, June 2021

\section{DAFTAR PUSTAKA}

\section{Al-Qur'an}

Kementerian Agama, Al-qur'an dan Terjemaban Dilengkapi dengan Asbabun Nuzul dan Hadist Sabih, Bandung: Sygma Examedia Arkanleema, 2007.

\section{Buku}

Ali Muhammad, Ash-Shalabi, Fikih Tamkin, Panduan meraih Kemenangan dan Kejayaan Islam, Jakarta: Pustaka Al-Kautsar, 2006.

Al-Jauziyah, Ibnu Qayyim, Hukum Acara Peradilan Islam, Yogyakarta: pustaka Pelajar, 2007.

Al-Majid Al-Khaldi, Mahmud Abd, Pilar-Pilar Sistem Pemerintahan Islam, Bogor: Al-Azhar Press, 2013.

Anwar al-Baz, Amir al- Jazzar, Fatwa-Fatwa Ibnu Taimiyah, Khilafah Islamiyah, Memerangi Pemberontak, Hukum Murtad, Pengadilan Negara, Sumpah dan Nazar, Makan Halal dan Haram, Jakarta: Pustaka Sahifa, 2008.

Djalil, H. A. Basiq, Peradilan Islam, Jakarta: Sinar Grafika Offset, 2012.

Iqbal, Muhammad, Fiqih Siyasah Kontekstualisasi doktrin Politik Islam, Jakarta: Gaya Media Pratama, 2001.

Manan, Munafrizal, Penemuan Hukum oleh Mabkamah Konstitusi, Bandung: Mandar Maju, 2012.

MD, Moh. Mahfud dkk, Constitutional Question Alternatif Baru Pencarian Keadilan Konstitutional, Malang: Universitas Brawijaya Press, 2010.

Mukhlas, Oyo Sunaryo, Perkembangan Peradilan Islam dari Kahin di Jazirah Arab ke Peradilan Agama di Indonesia, (Bogor: Ghalia Indonesia, 2011.

Mushthafa al-khan Ali al-Syurbaj, dan Mushthafa al-Bughai, Fikih Manhaji, kitab Fikih Lengkap Imam asy-Syafi'I, Yogyakarta: Darul Uswah, 2008.

Pulungan, J. Suyuthi, Fiqih Siyasah, Ajaran Sejarah dan Pemikiran, (Jakarta: RajaGrafindo Persada, 1999.

Salam Madkur, Muhammad, Peradilan dalam Islam, Surabaya: Toko Buku Percetakan Offset, 1993.

Saleh, Imam Anshori, Konsep Pengawasan Kehakiman, Malang: Setara Press, 2014.

Shiddiqie, Hasbi Ash, Sejarah Peradilan Islam, Jogjakarta: Bulan Bintang, 1970.

Sutiyoso, Bambang, Metode Penemuan Hukum, Upaya Mewnjudkan Hukum yang pasti dan Berkeadilan, , Yogyakarta: UII Press Yogyakarta, 2007.

Syahrur, Muhammad, Tirani Islam Genealogi Masyarakat dan Negara, Yogyakarta: LkiS Yogyakarta. 
Tall, Abd. Halim i, Asas-Asas Peradilan dalam Risalah Al-Qada, Kritik Terhadap Beberapa Asas Peradilan di Indonesia, Yogyakarta: UII Press Yogyakarta, 2014.

Watni Marpaung, Faisan Ananda, Metodologi Penelitian Hukum Islam, Jakarta: Prenada Media Group.

Yaqin, Areif Ainul, Constitutional Question, Kewenangan yang Terlupakan dan Gagasan Untuk. Melembagakannya di Mabkamah Konstitusi, Jakarta: Sinar Grafika, 2018.

\section{Jurnal}

Faiz, Joshua Satria Collins dan Pan Mohammad, Penambahan Kewenangan Constitutional Question di Mabkamah Konstitusi sebagai Upaya untuk. Melindungi HakHak Konstitusional Warga Negara, Jurnal Konstitusi, Volume 15, Nomor 4, Desember 2018, di akses pada 10Januari 2020.

Hanum, Cholida, Perda Syariah Perspektif Ketatanegaraan dan Siyasah Dusturiyyah, Jurnal Ilmu Syari'ah dan Hukum, Vol. 4, Nomor 2, 2019, di akses pada tgl 20-02-2021.

Pan Mohammad Faiz, Joshua Satria Collins, Penambahan Kewenangan Constitutional Question di Mahkamah Konstitusi sebagai Upaya untuk Melindungi Hak-Hak Konstitusional Warga Negara, Jurnal Konstitusi, Volume 15, Nomor 4, Desember 2018, di akses pada 3 Desember 2019.

Zoelfa, Hamdan, Constitutional Complaint dan Constitutional Question dan Perlindungan Hak-Hak Konstitusional Warga Negara, Jurnal Media Hukum, Vol. 19 NO.1 Juni 2012, di akses pada Sabtu, tgl 20, 2021.

\section{Putusan MK}

Lihat putusan perkara 013-022/PUU-IV/2006, permohonan dikabulkan dan Pasal 134, Pasal 136, serta Pasal 137 Kubap tentang Penghinaan terhadap Presiden atau Wakil Presiden dinyatakan bertentangan dengan UUD 1945 dan tidak memiliki kekuatan bukum mengikat. 